\title{
Pengaruh Waktu Pasteurisasi Terhadap Cemaran Mikrobiologis dan Aktivitas Antioksidan Loloh Daun Pohpohan (Pilea trinervia Wight.)
}

\section{The Effect of Pasteurization Time on The Microbiological Contamination and Antioxidant Activity on Loloh Pohpohan Leaves (Pilea trinervia Wight.)}

\author{
Icha Nabillah ${ }^{1}$, I Nengah Kencana Putra ${ }^{1^{*}}$, I Putu Suparthana ${ }^{1}$ \\ Program Studi Teknologi Pangan, Fakultas Teknologi Pertanian, Universitas Udayana \\ Kampus Bukit Jimbaran, Badung-Bali \\ *Penulis korespondensi: I Nengah Kencana, Email: nengahkencana@unud.ac.id
}

\begin{abstract}
Loloh is one of the traditional beverages in Bali made from fresh leaves, root, stem, seeds or fruit without cooking treatment (cold process). Some studies showed that loloh in several area in Bali is not worth to consume because of high level of microbial contamination. This study aimed to determine the effect of pasteurization time to produce loloh pohpohan leaves with the best antioxidant activity and free from microbial contamination. This experiment used a Completely Randomized Design with 7 variations of pasteurization treatment time, namely 0, 10, 15, 20, 2530 and 35 minutes. The treatment was repeated three time for obtain 21 experimental units. The data obtained were analyzed by analyze of variance and if the treatment had significant effect, then it was followed by Duncan Multiple Range Test (DMRT). The result of this study showed that pasteurization time has a very significant effect $(\mathrm{P}<0,01)$ on total microbial, total coliform and antioxidant activity. The best loloh treatment in this study was obtain with 20 minutes pasteurization time with the total plate count $0 \mathrm{CFU} / \mathrm{mL}$ (no microbes showed), negative coliform and antioxidant activity $58.39 \%$ with $\mathrm{IC}_{50}$ valued $1584.097 \mathrm{ppm}$, the color is neutral, the aroma is neutral, the taste was bitter and neutral and overall acceptance is neutral.
\end{abstract}

Keywords: loloh, pohpohan leaves, pasteurization, microbial contamination, antioxidant activity

\section{PENDAHULUAN}

Pohpohan merupakan tanaman indigenous yang banyak ditanam di dataran tinggi. Pohpohan dapat tumbuh dengan tinggi $0,5-2 \mathrm{~m}$, berbentuk elips dan tepi daun bergerigi (Siemonsma dan Piluek, 1994). Umumnya daun pohpohan dikonsumsi dalam bentuk mentah sebagai lalapan atau direbus. Hasil penelitian Mandarini (2014) menyebutkan bahwa pohpohan memiliki aktivitas antioksidan tertinggi sebesar 97,89 mg AEAC/100 g dibandingkan beberapa sayuran yang terdapat di Jawa Barat lainnya yaitu daun singkong, kecombrang, kemangi, katuk, selada, bayam, kangkung, genjer dan brokoli. Pohpohan juga memiliki kandungan senyawa quersetin sebesar
$1,76 \mathrm{mg}$, kaemferol $0,25 \mathrm{mg}$, luteolin $0,33 \mathrm{mg}$, antosianin $0,75 \mathrm{mg}$, asam klorogenat $17,47 \mathrm{mg}$, asam kafeat 1,11 mgasam ferulat $0,17 \mathrm{mg}$ dan total fenol 121,52 mg (Andarwulan dan Faradilla, 2012).

Hingga saat ini khususnya di Bali, daun pohpohan belum banyak diolah menjadi produk pangan dan sebagian masyarakat belum mengetahui bahwa daun tersebut dapat dikonsumsi. Oleh karena itu, salah satu upaya pemanfaatan daun pohpohan sebagai pangan fungsional adalah diolah menjadi minuman tradisional Bali yang telah banyak dikenal dan dikonsumsi masyarakat yaitu loloh. Loloh merupakan salah satu minum tradisional khas Bali 
yang terbuat dari ekstrak yang berasal dari tumbuhan misalnya pada bagian akar, batang, biji, buah serta daun atau bagian-bagian dari berbagai jenis tumbuhan memiliki khasiat sebagai obat (Kusumawati, 2016).

Cara pengolahan loloh tergolong sederhana sehingga banyak diproduksi dalam skala rumah tangga. Loloh diolah dengan cara diekstraksi langsung dari daun segar dengan cara diremas tanpa proses pemanasan. Cara pengolahan loloh yang sederhana ini tidak menutup kemungkinan terdapat kontaminasi mikroba patogen salah satunya ialah coliform. Coliform merupakan suatu grup bakteri yang digunakan sebagai indikator adanya polusi kotoran dan kondisi yang tidak baik terhadap air, makanan, susu dan produk-produk susu. Adanya bakteri coliform dalam makanan dan minuman menunjukkan kemungkinan adanya mikroba enteropatogenik dan toksigenik yang berbahaya bagi kesehatan (Widianti dan Ristianti, 2004). Kartika et al., (2015) melaporkan bahwa tingkat cemaran coliform pada loloh yang dijual di daerah Denpasar mencapai 78,57\%, sehingga dapat dikatakan sebagian besar loloh tercemar oleh bakteri coliform. Maka dari itu untuk mengurangi cemaran mikroba pada loloh dapat dilakukan dengan cara pasteurisasi.

Pasteurisasi merupakan proses pemanasan pada suhu $60-100^{\circ} \mathrm{C}$ yang bertujuan untuk membunuh mikroorganisme seperti bakteri, kapang dan khamir dengan masih mempertimbangkan mutu bahan pangan tersebut (Fellow, 1992). Kusuma et al. (2007) melaporkan bahwa proses pasteurisasi dengan suhu $80^{\circ} \mathrm{C}$ menghasilkan jus jeruk pacitan dengan kualitas yang memiliki jumlah mikroba terendah yaitu $1,9 \times 10^{2} \mathrm{koloni} / \mathrm{ml}$ jus jeruk yang telah memenuhi SNI ( $\left.<2 \times 10^{2} \mathrm{koloni} / \mathrm{ml}\right)$, dan Fadil et al., (2016) melaporkan bahwa pasteurisasi dengan suhu 77-88 ${ }^{\circ} \mathrm{C}$ dengan waktu 30 menit menghasilkan sari ubi jalar ungu dengan kualitas terbaik. Proses pasteurisasi juga dapat mempengaruhi aktivitas antioksidan dalam suatu produk, suhu dan waktu yang tepat dapat menghasilkan produk dengan aktivitas antioksidan tertinggi, namun apabila suhu dan waktu yang digunakan terlalu tinggi maka dapat menyebabkan kerusakan senyawa antioksidan dalam produk. Penelitian yang dilakukan oleh Gupita (2012) melaporkan bahwa sari kulit buah manggis dengan $\mathrm{pH} 4$ dan suhu pasteurisasi $85^{\circ} \mathrm{C}$ memiliki aktivitas antioksidan tertinggi yaitu $89,70 \%$.

Hingga saat ini belum dilakukan penelitian terkait waktu pasteurisasi yang tepat untuk menjaga aktivitas antioksidan dan mencegah kontaminasi mikroba patogen pada loloh. Oleh karena itu penelitian ini bertujuan untuk mengembangkan daun pohpohan menjadi minuman tradisional loloh serta mengetahui pengaruh waktu pasteurisasi terhadap cemaran mikrobiologis dan aktivitas antioksidan loloh daun pohpohan.

\section{METODE}

\section{Tempat dan Waktu Penelitian}

Penelitian dilaksanakan di Laboratorium Pengolahan Pangan, Laboratorium Mikrobiologi pangan dan Laboratorium Analisis Pangan Fakultas Teknologi Pertanian Universitas 
Udayana. Waktu penelitian berlangsung dari bulan September sampai Oktober 2020.

\section{Bahan dan Alat}

Bahan yang digunakan dalam penelitian adalah daun pohpohan muda dan segar dengan ciri berwarna hijau muda dan berjumlah 4 dari atas puscuk daun yang diperoleh di hutan kebun raya Bedugul, Tabanan, Bali, metanol, aquades, 2,2diphenyl-1-picrylhydrazyl (DPPH), media plate count agar (merck), peptone water (merck), media lactose broth (oxoid), air kemasan, kertas saring, aluminium foil, kertas buram, karet gelang, kantung plastik, kapas, spirtus, alkohol 70\% dan kertas label.

Alat-alat yang digunakan dalam penelitian ini adalah kompor, dandang, baskom, blender, saringan, autoclave, laminar air flow, inkubator, spektrofotometer (Genesys 10S UV-Vis), timbangan analitik (Shimadzu ATY224), vortex, pipet tetes, pipet mikro, tip, botol kaca, bunsen, batang bengkok, cawan petri, tabung reaksi, rak tabung reaksi, spatula, corong, labu ukur, gelas beaker, gelas ukur, erlenmeyer dan kuvet.

\section{Rancangan Penelitian dan Analisa Data}

Rancangan yang digunakan pada penelitian ini adalah Rancangan Acak Lengkap (RAL) dengan perlakuan waktu pasteurisasi yang terdiri dari 7 taraf yaitu; $\mathrm{T} 0=0$ menit, $\mathrm{T} 1=10$ menit, $\mathrm{T} 2=15$ menit, $\mathrm{T} 3=20$ menit, $\mathrm{T} 4=25$ menit, $\mathrm{T} 5=30$ menit, $\mathrm{T} 6=35$ menit dan diulang sebanyak 3 kali sehingga diperoleh 21 unit percobaan. Data yang diperoleh dianalisis menggunakan sidik ragam (ANOVA) dan apabila perlakuan berpengaruh terhadap parameter yang diamati maka dilanjutkan dengan uji Duncan's Multiple Range Test (DMRT) (Gomez dan Gomez, 1995).

\section{Pembuatan Loloh Daun Pohpohan}

Penelitian ini diawali dengan melakukan pemetikan daun pohpohan yang muda berwarna hijau muda berjumlah 4 dari atas pucuk daun yang diperoleh di hutan kebun raya Bedugul, Desa Candikuning, Kecamatan Baturiti, Kabupaten Tabanan, Bali. Kemudian dilakukan sortasi daun untuk mendapatkan daun pohpohan yang segar dan juga utuh serta memisahkan daun dari batangnya. Selanjutnya daun pohpohan dicuci hingga bersih menggunakan air mengalir.

Daun pohpohan sebanyak 50 g kemudian dihaluskan menggunakan blender. Dipanaskan air sebanyak $500 \mathrm{ml}$ hingga suhu $80^{\circ} \mathrm{C}$, kemudian daun pohpohan yang telah dihaluskan dimasukkan kedalam air tersebut dan di panaskan sesuai perlakuan yaitu 10 menit, 15 menit, 20 menit, 25 menit, 30 menit dan 35 menit kemudian disaring. Setelah loloh selesai dipasteurisasi kemudian ditambahkan garam sebanyak $1 \%$ dari jumlah volume loloh yang didapatkan.

\section{Parameter yang diamati}

Parameter yang diamati pada penelitian ini adalah Total Mikroba (Fardiaz, 1992), Total Coliform (Fardiaz, 1992), Aktivitas Antioksidan (Blois, 1985 dalam Hanani et al., 2005) dan Evaluasi Sensoris (Soekarto, 1985).

\section{HASIL DAN PEMBAHASAN}

\section{Total Mikroba}

Hasil pengujian total mikroba dan coliform loloh daun pohpohan dapat dilihat pada Tabel 1 . Berdasarkan hasil pengujian TPC pada loloh daun 
pohpohan menunjukkan adanya pengurangan jumlah mikroba akibat proses pasteurisasi. Semakin lama waktu pasteurisasi maka jumlah mikroba yang terdapat dalam loloh daun pohpohan semakin berkurang. Mikroba dalam suatu produk dapat disebabkan oleh beberapa hal yaitu heginitas baik dari alat maupun dari bahan yang digunakan dalam proses produksi. Pada hasil pengujian TPC angka tertinggi terdapat pada loloh dengan perlakuan kontrol atau tanpa proses pasteurisasi yaitu sebesar $7,3 \times 10^{3} \mathrm{CFU} / \mathrm{mL}$ dan setelah proses pasteurisasi selama 10 menit jumlah mikroba mulai berkurang menjadi $3,3 \times 10^{2} \mathrm{CFU} / \mathrm{mL}$, proses pasteurisasi ini menyebabkan sebagian mikroba mati sehingga jumlah mikroba berkurang dibandingkan pada perlakuan kontrol, pada pasteurisasi dengan waktu 15 menit hingga 35 menit hasil pengujian menunjukkan jumlah mikroba menjadi 0 atau tidak terdapat mikroba yang tumbuh.

Tabel 1. Nilai rata-rata total mikroba dan coliform loloh daun pohpohan.

\begin{tabular}{ccc}
\hline Waktu Pasteurisasi & Total Mikroba $(\mathrm{CFU} / \mathrm{mL})$ & Coliform $(\mathrm{MPN} / \mathrm{mL})$ \\
\hline 0 menit & $7,3 \times 10^{3}$ & $1,1 \times 10^{4}$ \\
10 menit & $3,3 \times 10^{2}$ & negatif \\
15 menit & - & negatif \\
20 menit & - & negatif \\
25 menit & - & negatif \\
30 menit & - & negatif \\
35 menit & - & negatif \\
\hline Keterangan: CFU Colony Forming Unit & & \\
MPN $\quad$ Most Probable Number &
\end{tabular}

Proses pemanasan dapat mengurangi jumlah mikroba dalam sampel. Proses pasteurisasi sendiri merupakan proses pemanasan dengan suhu di bawah $212^{\circ} \mathrm{F}\left(100^{\circ} \mathrm{C}\right)$ yang bertujuan untuk membunuh atau memperlambat pertumbuhan mikroba pathogen yang dapat memperpanjang masa simpan (Ningsih et al., 2014). Berdasarkan laporan FAO/WHO tahun 1970 dan Moatz (1982) dalam Abubakar et al., (2001) pasteurisasi pada umumnya dapat mengurangi jumlah kuman 9099\%, bergantung pada jenis dan jumlah kuman sebelum proses pasteurisasi. Berdasarkan Standar Nasional Indonesia (SNI) 7388:2009 ditetapkan bahwa kandungan mikroba dalam produk minuman $<10^{6}$ koloni/mL (Pratiwi, 2005). Hal ini menunjukkan bahwa loloh daun pohpohan ini masih layak dikonsumsi.

\section{Total Coliform}

Hasil nilai rata-rata MPN coliform loloh daun pohpohan dapat dilihat pada Tabel 1 . Berdasarkan hasil pengujian total coliform produk loloh daun pohpohan diketahui perlakuan pasteurisasi mampu mengurangi total coliform dalam produk. Loloh daun pohpohan yang mendapat perlakuan pasteurisasi negatif mengandung coliform yang ditandakan tidak adanya gelembung udara pada tabung durham. Sementara loloh daun pohpohan dengan perlakuan kontrol (tanpa pasteurisasi) positif tercemar mikroba coliform yang ditandai dengan munculnya 
gelembung pada tabung durham serta perubahan warna dari media yang digunakan. Sampel yang menunjukkan hasil positif disebabkan karena bakteri tersebut memfermentasikan laktosa yang menghasilkan asam dan gas pada tabung BGLB (Widiyanti, 2002 dalam Sunarti, 2015).

Perhitungan MPN (Most Probable Number) pada perlakuan kontrol yaitu sebesar $1,1 \times 10^{4} \mathrm{MPN} / \mathrm{mL}$. Berdasarkan surat keputusan dirjan POM (SNI) 7388:2009 yaitu cemaran coliform maksimum sebesar $20 \mathrm{MPN} / \mathrm{mL}$ yang berarti produk loloh daun pohpohan tanpa perlakuan pasteurisasi ini tidak layak di konsumsi karna melewati batas maksimum yang telah ditetapkan. Loloh daun pohpohan tanpa perlakuan pasteurisasi positif tercemar coliform dapat disebabkan oleh penggunaan air untuk pembuatan produk maupun untuk mencuci daun telah tercemar coliform. Keberadaan bakteri coliform dapat menyebabkan beberapa penyakit khususnya yaitu diare. Adanya coliform dalam air menunjukkan bahwa air tersebut telah tercemar oleh bakteri Eschericia coli.

\section{Aktivitas Antioksidan}

Hasil analisis aktivitas antioksidan loloh daun pohpohan dapat dilihat pada Tabel 2.

Tabel 2. Nilai rata-rata aktivitas antioksidan loloh daun pohpohan

\begin{tabular}{cc}
\hline Waktu Pasteurisasi & Aktivitas Antioksidan (\%) \\
\hline 0 menit & $12,84 \pm 0,93 \mathrm{f}$ \\
10 menit & $27,55 \pm 0,30 \mathrm{~d}$ \\
15 menit & $40,35 \pm 0,42 \mathrm{~b}$ \\
20 menit & $58,39 \pm 0,50 \mathrm{a}$ \\
25 menit & $36,49 \pm 0,64 \mathrm{c}$ \\
30 menit & $27,23 \pm 0,82 \mathrm{~d}$ \\
35 menit & $18,53 \pm 0,85 \mathrm{e}$ \\
\hline
\end{tabular}

Keterangan: Nilai rata-rata \pm standar deviasi $(\mathrm{n}=3)$. Huruf yang berbeda dibelakang nilai rata-rata pada kolom yang sama menunjukkan perbedaan yang nyata $(\mathrm{P}<0,05)$.

Hasil sidik ragam menunjukkan bahwa perlakuan waktu pasteurisasi berpengaruh sangat nyata $(\mathrm{P}<0,01)$ terhadap aktivitas antioksidan loloh daun pohpohan. Berdasarkan Tabel 2 nilai antioksidan loloh daun pohpohan berkisar antara 12,84\%-58,39\%. Aktivitas antioksidan tertinggi terdapat pada perlakuan pasteurisasi 20 menit yaitu sebesar $58,39 \%$ dan terendah pada perlakuan kontrol (pasteurisasi 0 menit) 12,84\%. Pada perlakuan waktu pasteurisasi 0 menit hingga 20 menit terjadi kenaikan aktivitas antioksidan, hal ini dikarenakan proses pemanasan dapat membantu memecah atau membuka jaringan yang terdapat pada daun pohpohan sehingga komponen aktif daun tersebut dapat terekstrak keluar. Proses pemanasan sayuran dapat menyebabkan kerusakan pada dinding sel tanaman sehingga senyawa dalam sel termasuk senyawa antioksidan keluar dari sel dan masuk kedalam pelarut air (Momuat et al., 2010). Reische et al., (2002) dalam Momuat (2010) juga menyatakan bahwa beberapa senyawa antioksidan akan lebih aktif jika dipanaskan karena 
peranannya dalam reaksi pencoklatan nonenzimatik, sedangkan korotenoid mencapai kestabilan jika dipanaskan sehingga kegunaannya sebagai antioksidan semakin membaik.

Sedangkan pada waktu pasteurisasi 25 menit-35 menit terjadi penurunan kembali aktivitas antioksidan, hal ini dikarenakan senyawa antioksidan mulai mengalami kerusakan akibat waktu pemanasan. Hal ini sesuai dengan pernyataan Patran et al., (2009) yaitu senyawa antioksidan akan mudah terdegradasi bila terkena suhu tinggi dalam waktu yang lama. Hal ini disebabkan senyawa antioksidan kehilangan kemampuannya mendonorkan elektron untuk menetralkan senyawa radikal. Pokorny et al., (2001) juga melaporkan pemanasan dapat menyebabkan terjadinya percepatan reaksi inisiasi dan penurunan aktivitas antioksidan dikarenakan senyawa metabolit sekunder yang berperan sebagai antioksidan mengalami kerusakan sehingga kurang mampu mereduksi radikal bebas dengan baik.

Selanjutnya perlakuan aktivitas antioksidan tertinggi yang diperoleh dari waktu pasteurisasi 20 menit dilakukan pengujian $\mathrm{IC}_{50}$. $\mathrm{IC}_{50}$ merupakan konsentrasi suatu zat antioksidan yang dapat menghambat radikal bebas sebanyak 50\% (Molyneux, 2004). Nilai $\mathrm{IC}_{50}$ loloh daun pohpohan dengan perlakuan pasteurisasi 20 menit yaitu sebesar 1584,097 ppm. Semakin rendah nilai $\mathrm{IC}_{50}$ maka semakin tinggi kandungan aktivitas antioksidan dalam bahan tersebut. Menurut Molyneux (2004) klasifikasi IC $_{50}$ dibagi menjadi 5 yaitu $<50$ ppm (sangat kuat), 50-100 ppm (kuat), 100-150 ppm (sedang), 150-200 ppm (lemah) dan $>200$ ppm (sangat lemah). Maka dari itu nilai $\mathrm{IC}_{50}$ dari loloh daun pohpohan ini tergolong sangat lemah karena $>200$ ppm.

\section{Evaluasi Sensori}

Pengujian sifat sensoris pada penilitian ini dilakukan dengan uji hedonik terhadap warna, aroma, rasa dan penerimaan keseluruhan. Pengujian skoring dilakukan terhadap rasa pahit. Nilai rata-rata kesukaan terhadap warna, rasa, aroma, penerimaan keseluruhan dan skor rasa pahit dapat dilihat pada Tabel 3.

Tabel 3. Nilai rata-rata kesukaan dan skor rasa pahit loloh daun pohpohan.

\begin{tabular}{cccccc}
\hline $\begin{array}{c}\text { Waktu } \\
\text { Pasteurisasi }\end{array}$ & Warna & Aroma & Rasa & $\begin{array}{c}\text { Penerimaan } \\
\text { Keseluruhan }\end{array}$ & Skoring Rasa \\
\hline 10 menit & $3,28 \pm 1,02 \mathrm{a}$ & $3,28 \pm 0,93 \mathrm{a}$ & $3,08 \pm 0,99 \mathrm{a}$ & $3,24 \pm 1,01 \mathrm{a}$ & $2,84 \pm 1,02 \mathrm{bc}$ \\
15 menit & $3,60 \pm 1,15 \mathrm{a}$ & $3,40 \pm 1,04 \mathrm{a}$ & $3,00 \pm 1,08 \mathrm{a}$ & $3,28 \pm 1,17 \mathrm{a}$ & $2,80 \pm 0,91 \mathrm{bc}$ \\
20 menit & $3,32 \pm 0,80 \mathrm{a}$ & $3,32 \pm 0,90 \mathrm{a}$ & $3,12 \pm 0,83 \mathrm{a}$ & $3,44 \pm 0,76 \mathrm{a}$ & $2,68 \pm 1,10 \mathrm{c}$ \\
25 menit & $3,68 \pm 1,10 \mathrm{a}$ & $3,60 \pm 1.08 \mathrm{a}$ & $3,44 \pm 0,82 \mathrm{a}$ & $3,80 \pm 0,86 \mathrm{a}$ & $2,96 \pm 0,79 \mathrm{abc}$ \\
30 menit & $3,48 \pm 0,77 \mathrm{a}$ & $3,60 \pm 0.86 \mathrm{a}$ & $3,44 \pm 0,96 \mathrm{a}$ & $3,64 \pm 0,49 \mathrm{a}$ & $3,32 \pm 0,85 \mathrm{ab}$ \\
35 menit & $3,60 \pm 0,70 \mathrm{a}$ & $3,32 \pm 0,98 \mathrm{a}$ & $3,20 \pm 1,22 \mathrm{a}$ & $3,24 \pm 1,01 \mathrm{a}$ & $3,40 \pm 0,70 \mathrm{a}$ \\
\hline
\end{tabular}

Keterangan: Nilai rata-rata \pm standar deviasi $(n=3)$. Huruf yang berbeda dibelakang nilai rata-rata pada kolom yang sama menunjukkan perbedaan yang nyata $(\mathrm{P}<0,05)$. 


\section{a. Warna}

Hasil sidik ragam menunjukkan bahwa perlakuan waktu pasteurisasi tidak berpengaruh $(\mathrm{P}>0,05)$ terhadap kesukaan panelis pada warna loloh daun pohphan. Tabel 3 menunjukkan nilai ratarata kesukaan panelis terhadap warna loloh daun pohpohan berkisar antara 3,28 hingga 3,68 yaitu biasa. Loloh daun pohpohan yang di pasteurisasi ini memiliki kenampakan warna hijau tua.

\section{b. Aroma}

Hasil sidik ragam menunjukkan bahwa perlakuan pasteurisasi tidak berpengaruh $(\mathrm{P}>0,05)$ terhadap aroma loloh daun pohpohan. Nilai rata-rata tingkat kesukaan panelis terhadap aroma dapat dilihat pada Tabel 3. Kesukaan panelis terhadap aroma loloh daun pohpohan berkisar antara 3,38 hingga 3,60 dengan kriteria biasa. Meilgaard et al., (2000) menyatakan aroma dari makanan timbul karena terbentuknya senyawa volatile. Senyawa volatile dapat hilang selama proses pengolahan terutama karena panas (Fellow, 1988).

\section{c. Rasa}

Pengujian terhadap rasa dilakukan dengan uji hedonik dan skoring, nilai hedonik dan skoring rasa dari loloh daun pohpohan dapat dilihat pada Tabel 3. Hasil sidik ragam uji skoring terhadap rasa pahit dari loloh daun pohpohan menunjukkan perlakuan berpengaruh nyata $(\mathrm{P}<0,05)$. Rata-rata nilai skoring terhadap rasa berkisar antara 2,80 (pahit) hingga 3,40 (agak pahit). Semakin lama waktu pasteurisasi, tingkat kepahitan dari loloh daun pohpohan berkurang. Hal ini dapat disebabkan oleh kandungan tanin yang terdapat dalam daun pohpohan. Proses pemanasan menyebabkan tanin terekstrak dan bercampur dengan pelarut air, namun setelah mencapai titik optimal beberapa senyawa termasuk tanin akan mengalami penurunan dikarenakan tanin mengalami kerusakan akibat pemanasan yang berlangsung terus menerus (Sukardi et al., 2007). Hal tersebut menyebabkan rasa pahit dari loloh pohpohan berkurang seiring dengan lamanya waktu pasteurisasi karena rusaknya kandungan tanin.

Pengujian rasa selanjutnya yaitu uji hedonik, hasil sidik ragam menunjukkan bahwa perlakuan waktu pasteurisasi tidak berpengaruh $(\mathrm{P}>0,05)$ terhadap tingkat kesukaan panelis terhadap rasa loloh daun pohpohan. Nilai rata-rata kesukaan panelis terhadap rasa loloh daun pohpohan berkisar antara 3,00 hingga 3,40 yaitu biasa. Hal ini dapat disebabkan rasa pahit yang dimiliki loloh daun pohpohan sehingga panelis tidak terlalu menyukai rasa dari loloh daun pohpohan.

\section{d. Penerimaan Keseluruhan}

Penerimaan keseluruhan dipengaruhi oleh beberapa faktor diantaranya yaitu warna, aroma dan rasa dari produk tersebut. Hasil sidik ragam menunjukkan bahwa perlakuan waktu pasteurisasi tidak berpengaruh $(\mathrm{P}>0,05)$ terhadap penerimaan keseluruhan loloh daun pohpohan. Nilai rata-rata penerimaan keseluruhan loloh daun pohpohan seperti pada Tabel 3, yaitu 3,24 hingga 3,80 yaitu biasa. 


\section{KESIMPULAN}

Berdasarkan hasil penelitian di atas, dapat disimpulkan bahwa waktu pasteurisasi berpengaruh sangat nyata terhadap total mikroba, bakteri coliform, aktivitas antioksidan, rasa (uji skoring) dan tidak berpengaruh pada kesukaan terhadap warna, aroma, rasa dan penerimaan keseluruhan loloh daun pohpohan. Hasil penelitian menunjukkan bahwa waktu pasteurisasi 20 menit merupakan perlakuan terbaik dengan karakteristik sebagai berikut: total mikroba $0 \mathrm{CFU} / \mathrm{mL}$, negatif bakteri coliform, aktivitas antioksidan 58,39\% dengan nilai $\mathrm{IC}_{50}$ 1584,097 ppm serta kesukaan terhadap warna, aroma, rasa, dan penerimaan keseluruhan biasa, serta rasa pahit.

\section{DAFTAR PUSTAKA}

Abubakar., R. Triyantini., H. Setiyanto., dan Nurjannah. (2001). Pengaruh susu dan waktu pasteurisasi terhadap mutu susu selama penyimpanan. Jurnal Ilmu Ternak Veteriner. 6(1): 45-50.

Anonim. (2005). Standard Methods for the Examination of Water and Wastewater. Amer. Publ. 17th Edition. American Public Health Association. New York Health Association.

Almatsier, S. (2004). Prinsip Dasar Ilmu Gizi. PT Gramedia Pustaka Utama. Jakarta.

Andarwulan, N., R. Batari, D.A. Sandrasari, B. Bolling, dan H. Wijaya. (2010). Flavonoid content and antioxidant activity of vegetables from Indonesia. Food Chem. 121:1231-1235.

Arnia, dan W. Efrida. (2013). Identifikasi kontaminasi bakteri coliform pada daging sapi segar yang dijual di pasar sekitar Kota Bandar Lampung. Medical Journal of Lampung University.43-50.

Agung, I.G.A.A., I.K. Sumantra., dan I.K. Widnyana. (2016). Pangan, Gizi dan Kesehatan Masyarakat. UNMAS Press. Bali.

Bejan, Adrian, dan K. Alan. (2003). Heat Transfer Handbook. Canada: John Wiley and Sons, Inc.
Batari, R. (2007). Identifikasi Senyawa Flavonoid Pada Sayuran Indigenous Jawa Barat. Bogor: Fakultas Ilmu dan Teknologi Pangan, Institut Pertanian Bogor.

Batt, C.A. (2014). Classical and Modern Methods for Detections and Enumeration: Coliform Bacteria. Elsavier Ltd. USA.: 610-617.

Desmiati, S. (2001). Kajian serat pangan dan antioksidan alami beberapa jenis sayuran serta daya serap dan retensi antioksidan pada tikus percobaan. Tesis. Program Pascasarjana Ilmu Pangan Institut Pertanian Bogor. Bogor.

Dwiyani, R. (2008). Identifikasi Golongan Senyawa Antioksidan Pada Daun Pohpohan (Pilea trinevia). Institut Pertanian Bogor.

Fadil, S., Sui, M., dan Sudiyono. (2016). Pengaruh Pasteurisasi dan Sterilisasi Terhadap Kualitas dan Lama Penyimpanan Sari Ubi Jalar Ungu (Ipomea batatas L.). Jurnal ilmu-ilmu Pertanian Agrika. 10(1).

Fardiaz. (1992). Mikrobiologi Pangan 1. Gramedia Pustaka Utama, Jakarta.

Fellow, P.J. (1992). Food Processing Technology. CRC Press. New York.

Gupita, C.N. (2012). Pengaruh Berbagai pH Sari Buah Dan Pasteurisasi Terhadap Aktivitas Antioksidan dan Tingkat Penerimaan Sari Kulit Buah Manggis. Universitas Diponegoro Semarang.

Hanani, E.A., Mun'im dan Sekarini, E. (2005). Identifikasi Senyawa Antioksidan dalam Spons Callyspongia $s p$. dari Kepulauan Seribu. Majalah Ilmu Kefarmasian. 2(3): 127-133.

Harborne, J.B. (1987). Metode Fitokimia Penuntun Cara Modern Menganalisis Tumbuhan, diterjemahkan Kosasih Padmawinata, Edisi II, Penerbit ITB, Bandung, 71-72.

Harris, R.S., dan E. Karmas. (1989). Evaluasi Gizi Pada Pengolahan Bahan Pangan. Penerbit ITB. Bandung.

Hawa, L.C. dan R.I. Putri. (2011). Penerapan pulsed electric field pada pasteurisasi sari buah apel varietas ana: kajian karakteristik nilai gizi, sifat fisik, sifat kimiawi dan mikrobia total. Agritech, 31(4).

Jiwintarum, Y., Agrijanti., dan B.L. Septiana. (2017). Most probable number (MPN) coliform dengan variasi volume media lactose broth single strength (LBSS) dan lactose broth double strength (LBDS). Jurnal Kesehatan Prima 11(1): 11-17. 
Koeswardhani, M.M. (2006). Pengantar Teknologi Pangan. Penerbit Universitas Terbuka. Jakarta. Kusuma, H.R., T. Ingewati., N. Indraswati., dan Martina. (2007). Pengaruh pasteurisasi terhadap kualitas jus jeruk pacitan. Widya Teknik, 6(2):142-151.

Kusumawati, I.G.A.W., I.P. Darmawijaya., dan I.B.A. Yogeswara. (2014). Potensi antioksidan loloh tempuyung (Sonchusarvensis L.) Sebagai minuman fungsional. Prosiding Seminar Nasional Biologi FMIPA UNHI.

Kusumawati, I.G.A.W., I.P. Darmawijaya., dan I.B.A. Yogeswara. (2016). Formulasi dan kemampuan menangkal radikal bebas dari loloh sembung (Blumea balsamifera). Traditional Medicine Journal, 21(3).

Khurniyati, M.I. dan T. Estiasih. (2015). Pengaruh konsentrasi natrium benzoat dan kondisi paseurisasi (suhu dan waktu) terhadap karakteristik minuman sari apel berbagai varietas. Jurnal Pangan dan Agroindustry 3(2): 523-529.

Kartika, I.D.P., I.K. Suter., P. Arisandi., dan A.A.I.S. Wiadnyani. (2015). Prevalensi Cemaran Mikrobiologis dan Logam Berat (PB, CD) Pada Minuman Tradisional (Loloh) di Derah Denpasar dan Badung. Prosiding Seminar Nasional Sains dan Teknologi II 2015 Universitas Udayana. Bali.

Mulyati, N.D. (1994). Mempelajari pengaruh metode pemasakan terhadap stabilitas karoten pada beberapa sayuran hijau. Skripsi. Jurusan Gizi Masyarakat dan Sumber Daya Keluarga, Institut Pertanian Bogor, Bogor.

Molyneux, P. (2004). The use of the stable free radical diphenylpicryl-hydrazyl (DPPH) for estimating antioxidant activity. Songklanakarin J. Sci. Technol. 26(2), 211-219.

Momuat, L., F. Fatimah., F. Wehantow., dan O. Mamondol. (2010). Efek pemanasan terhadap total antioksidan dari beberapa jenis sayur tinutuan. Chem. Prog. 3(2): 85-90.

Monro, A.K. (2004). Three new species and three new name in Pilea (Urticaceae) from New Guinea. Kew Bull. 59:573-579.

Mandarini, N.P. (2014). Analisis Kapasitas Antioksidan dan Kandungan Total Fenol Pada Sayuran. Institut Pertanian Bogor.

Muntikah dan M. Razak. (2017). Ilmu Teknologi Pangan. Pusat Pendidikan Sumber Daya Manusia Kesehatan. Jakarta.
Miranti, A. (2018). Formulasi Minuman Berbasis Daun Pohpohan (Pilea trinervia W.) sebagai pangan fungsional. Institut Pertanian Bogor.

Nathalie, Liesbeth Leurs. (2009). Medicinal, Aromatic and Cosmetic (MAC) Plants for Community Health and Bio-Cultural Diversity Conservation in Bali, Indonesia. L.N: 124-127.

Ningsih, M., Setyawati, T.R dan Mukarlina. (2014). Kualitas susu cair pasta pasteurisasi setelah penambahan sirup oligofruktosa umbi talas kimpul (Xanthomonas sagitifolium Schott). Jurnal Probiont. 3(2): 93-99.

Ninariyani, K. (2017). Induksi akar dan tunas stek batang tanaman pohpohan (Pilea trinervia W.) dakam media air dengan perlakuan IBA dan Aerasi. Institut Pertanian Bogor.

Novianti. (2017). Formulasi jelly drink ekstrak daun pohpohan (Pilea trinervia W.) sebagai alternatif pangan fungsional. Institut Pertanian Bogor.

Pratiwi, S.T. (2005). Pengujian cemaran bakteri dan cemaran kapang/khamir pada produk jamu gendong di Daerah Istimewa Yogyakarta. PHARMACON, Vol. 6(1): 10-15.

Putra, V.G.P. (2015). Pengaruh Kinetin Dan Asam 2,4 diklorofenoksiasetat Terhadap Kandungan Metabolit Sekunder Kalus Daun Pohpohan (Pilea trinervia Wight). Universitas Atma Jaya Yogyakarta.

Putra, I.G.N.A., N.L.A Yusasrini. dan I.W.R. Widarta. (2019). Pengaruh lama perebusan terhadap karakteristik loloh don piduh (Centella asiatica L.). Jurnal Ilmu dan Teknologi Pangan. 8(2): 189-196.

Parwata, I.M.O.A. (2016). Bahan Ajar Kimia Terapan: Antioksidan. Program Pascasarjana Universitas Udayana. Bali.

Pramana, D., N.L.A.K. Yuniastari., dan R.K. Wiyati. (2016). Loloh Daun Cemcem. Majalah Aplikasi Iptek Ngayah. 7(1).

Rahayuningsih, N. (2014). Uji aktivitas antidiabetes ekstrak etanol daun pohpohan (Pilea trinevia Wight.) pada mencit putih jantan Swiss Webster. Jurnal Kesehatan Bakti Tunas Husada. 12(1): 1-9.

Sari, P.W.N., I.B.P. Gunadnya., dan G. Arda. (2017). Penentuan umur simpan loloh piduh dengan metode accelerated shelf life testing (ASLT) menggunakan pendekatan model Arrhenius. Jurnal Beta (Biosistem dan Teknik Pertanian). $5(1): 28-34$. 
Soekarto, S.T. (1985). Penilaian Organoleptik untuk Industri Pangan dan Hasil Pertanian. Bhratara Karya Aksara. Jakarta.

Sukardi., A.R. Mulyarto., dan W. Safera. (2007). Optimasi waktu ekstraksi terhadap kandungan tanin pada bubuk ekstrak daun jambu biji (Psidii Folium) serta biaya produksinya. Jurnal Teknologi Pertanian. 8(2): 88-94.

Sunarti, R.N. (2015). Uji kualitas air sumur dengan menggunakan metode MPN (Most Probable Numbers). Bioilmi. 1(1): 30-34.

Trilaksani, W. (2003). Antioksidan: Jenis, Sumber, Mekanisme Kerja, dan Peran Terhadap Kesehatan. Fakultas Perikanan dan Kelautan, Institut Pertanian Bogor.

Tezar, R., A. Syarifah. (2014). Pengaruh pemasakan terhadap kandungan antioksidan sayuran. Buletin Pertanian Perkotaan 4(2):07 - 13.

Widyati, R. (2001). Pengetahuan Dasar Pengolahan Makanan Indonesia. PT. Grasindo. Jakarta.

Widiyanti, N.L.P.M. dan N.P. Ristanti. (2004). Analisis kuantitatif bakteri koliform pada depo air minum isi ulang di Kota Singaraja Bali. Jurnal Ekologi Kesehatan. 3(2): 64-73.

Yuliani, A., dan M. Rasdiansyah. (2014). Pengaruh Pemanasan Terhadap Aktivitas Antioksidan Pada Beberapa Jenis Sayuran. J. Teknologi Dan Industri Pertanian Indonesia. 06(02).

Yoppi, I., dan M. Resmi. (2018). Isolation and identification of chemical compounds from ethyl acetate fraction of Pohpohan (Pilea trinervia L.) leaves. Drug Invention Today. 10(5). 